\title{
Study on the Faith education of College Students based on \\ Jinggangshan spirit
}

\author{
Dawei Wang \\ East China university of Technology 330013,China
}

Keywords: Jinggangshan spirit; ideal faith;Outlook on life; values

\begin{abstract}
Jinggangshan spirit was founded by the older generation of revolutionaries, through continuous exploration and great practice of the formation ofJinggangshan spirit, for countless Communists to look forward to the victory of the revolution, and the relentless pursuit of revolutionary ideals. The new era of college students is the national training talents, national flower, the hope of the future, vigorously carry forward Jinggangshan spirit can help establish the ideals and beliefs of college students, improve morality and the ideological consciousness, and cultivate students' social sense of responsibility and mission, to promote the college students to form a correct outlook on life and values. In the face of an important transition period of social reform, strengthen the ideal and belief education of college students, the Communist Party for the inheritance of spiritual heritage, carry forward the party's fine tradition. Has important historical and practical significance to promote the social development of socialism with chinese characteristics.
\end{abstract}

\section{Introduction}

Jinggangshan spirit was formed in the revolutionary war period, it is a noble faith, countless men and women with high ideals shed their blood and sacrifice their lives in Jinggangshan,emerging Mao Zedong, Zhu De, Chen Yi, Su Yu and a large number of the great revolutionists, especially it got twoactively peasant troops at that time, combined with army of workers and peasants, together to suppress Kuomintang opposition, there are many fresh revolutionary hero known in this piece of red land left his mark, with his life for the victory of the revolution in Jinggangshan. Mao Zedong, Zhu De and other revolutionaries of the older generation in Jinggangshan, opened a "revolutionary road in the countryside surrounding the city, armed seize power", it is not only the cradle of the red revolution, after decades of years of baptism, it has become a timeless revolutionary spirit, left a valuable spiritual wealth for us of Jinggangshan spirit. Jinggangshan spirit is not a dogma, it needs to constantly develop and inheritance to future generations, contemporary college students are the pillars of the motherland, is the hope for prosperity and development, therefore, need to continue to strengthen and improve the education of ideals and beliefs of contemporary college students, enhance the collective concept, establish a scientific outlook on life and values.

\section{Current problems of college students' ideal and faith education}

An important period of strategic opportunities for contemporary college students coincides with the economic globalization, the globalization of trade development and prosperity, providing a platform for free play of the world market for the majority of college students, but the school education make the students thinking mode is limited in the test stage for a long time. They are lack of the confidence and courage to fight in the determination, the current of the times, vigorously 
promote, most college students are experience family education and social education domestication, their personal ideal and real life is the employment pressure buried, individualism, money worship the wind of serious flooding, and Chinese economy in recent years the rapid development of turbulent international and domestic situation, after the reform and opening up, the western culture a lot of thoughts and values from all sides swept, a serious impact on the western domestic cultural market, excellent traditional values is subtly changing. The rapid spread of network, change the ideological concept, the faith education of college students is facing with both opportunities and challenges, some ideas of freedom from the international mainstream, subversion of the contemporary college students' belief, students in the life study, by a large number of western thought influence effect, make college students lack of faith, this trend should not be underestimated. With the maturity of the socialist market economy in our country, the economic globalization and international trade development, thought system of college students are already out of the closed cage, the internationalization of more freedom, they thought more in line with international standards, more dynamic, more free, more variable. The news media, and network in the circle of friends of the spread, makes some sense of college students are quiet, however, some students are lack of sense of social responsibility, lack of faith, collective consciousness, fuzzy monetarism, in the face of major life choices, they can not make a correct judgment.

Economic globalization and international trade, and provide a broader perspective for the growth of college students, increasing students' experience, training the students' thinking pattern, and to a certain extent, the advanced ideas of students with international standards, from a new angle of research, using the new method, the majority of college students out of the fixed mode of the original thinking. But at the same time, the new idea for college students to bring fresh blood, some excellent spirit of the Chinese nation also weakened gradually, many students of the socialist confidence shaken, outlook on life and values, imperceptibly, western culture on contemporary college students' ideological penetration of wind blowing more fierce, a serious threat to healthy growth of college students.

\section{Strengthening and improving the college students' physical belief education needs guidance of revolutionary spirit}

General secretary Hu Jintao at the thirty-third Politburo collective study stressed that we must unremittingly to learn China revolutionary history, combining with the new era, carry forward our party formed in the revolutionary war period the glorious revolutionary tradition. Jinggangshan is the cradle of China revolution, 70 years ago, in Jinggangshan in our party struggle extremely hard and bitter, forming a "strong faith, hard work, pragmatic, dare to blaze a new road, the spirit of Jinggangshan, relying on the masses, the courage to win", as the Chinese revolution sowed the prairie fire, become the precious spiritual wealth of our party. General secretary Hu Jintao pointed out: "the great spirit of Jinggangshan reflects our party's fine tradition and style, we should combine the development of the times, with the changes of the historical position of the party and the historical task, combined with the new practice of reform and opening up, and the development of socialist market economy, to vigorously carry forward the spirit of Jinggangshan, in the new era under the condition of shed new light. and in October 14, 2004, the CPC Central Committee and the State Council issued "on Further Strengthening and improving ideological and political education", the central also emphasized to strengthen and improve college students' ideals and beliefs, to cultivate College Students' correct outlook on life and values, so as to make them form the noble moral sentiment. 
The value of Jinggangshan spirit in contemporary college students' ideal and faith education. Jinggangshan as the cradle of red revolution, the heritage of the older generation of revolutionaries by spreading the Jinggangshan red spirit, it is a kind of precious spiritual and cultural heritage, it has a positive effect on college students' ideal and faith education. The contemporary college students is the prosperity of the motherland is God's favored one, hope to strengthen college students' belief consciousness, cultivate their lofty moral ideal, it is conducive to the healthy growth of college students, provides excellent talents for the party and the country's long period of stability. After the failure of the great revolution,led by Mao Zedong and other revolutionaries of the older generation, lit a fire, the revolutionary armed workers and peasants of countless men and women with high ideals put their blood in Jinggangshan this piece of land, give the most beautiful youth to the party, to raise their life back to earth, eventually to defend the territory of the motherland, they death, fear of hardship, courageously forward, about an important moment in history, the revolutionary martyrs who kept a revolution of the dauntless spirit, down-to-earth and realistic, the basic principle of the Marx doctrine and Chinese revolutionary practice, opens up the countryside surrounding the city, the armed seizure of power in the revolutionary road, with characteristics of Party discipline and pure China firm revolutionary confidence building, to guide the Chinese revolution continue to a new glory, contemporary college students, in the older generation of life revolutionist make peace, don't eat bitter, didn't get tired, the spirit of the revolution without a clear system in their concept, coupled with the spread of western liberal thought, the university students' belief is not firm. ideals and beliefs are not purely problems. To maintain and develop the revolutionaries of the older generation bare-handed playing down the country, carry forward the revolutionary spirit of Jinggangshan, it is the contemporary to college students.

\subsection{The ideal and faith of contemporary college students need guidance of revolutionary spirit}

Good faith is a pillar of personal life, it is the pursuit of the target course to students in their own path of development, today's college students has been the ideal society gradually flood erosion, money worship thought, fantasy flourishes, distorted values, lack of realistic attitude, contrary to the theoretical system of the environment the whole and socialist harmonious society, the ideological and political theory course set up the ideals and beliefs of university students, they also does not have the desired effect, coupled with the reform of teaching practice of Ideological and political course, advocate relief in class, improve college students' ideal and faith education through the practice of Ideological and political course, it is more difficult to implement.

The ideal and conviction in the turbulent age of revolution, become a magic weapon for older outstanding communist party to win the final victory, with important essential factors of contemporary healthy growth of college students. Lofty ideals and beliefs is to improve college students' outlook on life and values of spiritual wealth, ideal and belief education of college students need more support, need to cultivate a socialist faith and confidence, to enable students to understand the reality of social economy, find out the development venation, grasp the trend of the times, the tradition of Chinese civilization, know yourself as a socialist the successors of the historical responsibility, established in Chinese under the leadership of the communist party taking the socialist road Chinese characteristics, to achieve the great rejuvenation of the China dream at the same time, we should vigorously promote the Okayama spirit, guide students to pursue higher goals, higher aspirations, set up a lofty communist ideal and belief. 


\section{Conclusion}

Marx's belief crisis in recent years around the many college students, many scholars at home and abroad began to doubt the radical correctness of Marx's theory, this trend has subtly affected the audience, some students showed contrary to the social core value system behavior, therefore, we should take strong the measures, and resolutely put an end to influence the wrong ideas of college students, reforming the Marx doctrine in the student population in glory, establish their belief in the Marx doctrine, the formation of correct ideals and beliefs.

During the period of Jinggangshan and will unite together for the ideals and beliefs of their struggle, rely on belief in the Marx doctrine, and the students of the new era to win the confidence of the revolution, for building a better future of the motherland's responsibility, has always been highly consistent with the party's thought, Marx's firm belief that we must understand to Marx "about things in the process of development progress and setbacks and new things overcome old things this Law deeply. Contemporary college students are growing in the greenhouse flowers, my sheltered environment, calm family, make their ability to solve problems and practical ability is slightly lacking, since the Jinggangshan revolutionary base was founded, the red spirit as a belief in eternal inheritance, inspired generations, until the rapid development in the environment of a harmonious society under the new China, still need to vigorously carry forward the spirit of revolution in Jinggangshan, to help students establish the correct ideals and beliefs.

A firm ideal and faith is a pure revolutionary spirit, it is the key to victory. The great Chinese communists, it is adhering to the conviction of the revolution, guiding the Marx doctrine, down-to-earth and realistic, to turn the tide and create great miracle in the history of the revolution, led the revolution to victory Chinese. our contemporary college students are lack of this revolutionary spirit, and the urgent need for the red revolution in Jinggangshan under the guidance of the spirit, school life, social practice through various ways, to infiltrate the surrounding university life, carry forward the mainstream culture of the red classics, to guide the students beliefs toward the right track, it is conducive to enhancing college students the political quality, cultivating qualified political talents, improve college students' ideal and faith education, cultivating excellent successors for the future development of China.

The historical experience of revolutionary struggle in Jinggangshan tells us that in order to achieve the victory of the revolution, armed struggle, united front, party leaders are indispensable, with strong theoretical guidance and route guidance at the same time, the firm ideal faith is a national key support in the victory that does not have a firm ideal faith to do support the nation is difficult to stand among the nations of the world. Party leaders always adhere to the fine tradition of the Chinese nation, hard work, dedication, can at the time of the social environment and living conditions of poor and blank, bare-handed to conquer the world, to defend their revolutionary achievements, a strong determination to rely on a strong revolutionary spirit and revolutionary victory.

\section{REFERENCES:}

[1]Zhang Y N. To Explore the "Jinggangshan Model" of Party Spirit Education based on the Unique Red Resources:A Case Study of CELAJ[J]. Journal of China Executive Leadership Academy Jinggangshan, 2010.

[2] Zhang G. A Study on How to Improve the Effectiveness of Party Spirit Education in Oilfield Companies_A Case Study of Zhongyuan Oilfield[J]. Journal of Sinopec Management Institute, 2016. 
[3] Zhang X G. On Learning the Jinggangshan Spirit and Strengthening the Ideal and Faith Education[J]. Journal of China Executive Leadership Academy Jinggangshan, 2009..

[4] Zhong L I, Zhang H. On the Time Value of Jinggangshan Spirit[J]. Journal of Jinggangshan University, 2010.

[5] Yan S, Luo X A. Discussion on the Value of the Red Books in Promoting Jinggangshan Spirit in Jiangxi Soviet Area's Revolutionary Struggle[J]. Sci-Tech Information Development \& Economy, 2011..

[6]Fernando M, Jackson B. The influence of religion-based workplace spirituality on business leaders’ decision-making: An inter-faith study[M]// Faculty of Commerce - Papers. 2006.

[7]Hall E L, Ripley J S, Garzon F L, et al. The Other Side of the Podium: Student Perspectives on Learning Integration[J]. Journal of Psychology \& Theology, 2009, 37(1):15-27.

[8]Hoppey D. A Case Study of Principal Leadership in an Effective Inclusive School.[J]. Journal of Special Education, 2013, 46(4):245-256.

[9]Sheridan M J, Wilmer C M, Atcheson L. INCLUSION OF CONTENT ON RELIGION AND SPIRITUALITY IN THE SOCIAL WORK CURRICULUM: A STUDY OF FACULTY VIEWS[J]. Journal of Social Work Education, 1994, 30(3):363-376. 